\title{
A VOZ DO VERME HÍBRIDO E TRANSTEMPORAL DE PEDRO KILKERRY
}

THE VOICE OF PEDRO KILKERRY'S HYBRID AND TRANSTEMPORAL WORM

Gabriel Costa Resende Pinto Bastos dos Santos*

Leonardo Davino de Oliveira** gabrielressantos@hotmail.com

Graduando em Letras Português-Japonês pela UERJ. Membro do projeto de pesquisa Poesia e Transdisciplinaridade: a vocoperformance.

*leonardo.davino@gmail.com

Doutor em Literatura Comparada, professor de Literatura Brasileira do Instituto de Letras da UERJ. Coordenador do projeto de pesquis Poesia e Transdisciplinaridade: a vocoperformance.

RESUMO: Pedro Militão Kilkerry (1885-1917) é um poeta simbolista baiano pouco conhecido, pouco pesquisado, e definitivamente muito evitado por sua fama de "difícil". Nosso trabalho concentra-se no poema "O verme e a estrela" de Pedro Kilkerry e na adaptação cancional do mesmo, levada a cabo por Cid Campos e registrada no disco A fábrica do poema (1994), de Adriana Calcanhotto, e no projeto verbivocovisual Poesia é risco (1995), de Augusto de Campos. O objetivo é elaborar uma reflexão sobre a potência viva e vivificante da voz e de sua vocoperformance, que expande o meramente gráfico para novas potências somente sugeridas e ocultas em estado-página, a partir de um poema tão extraordinário.

PALAVRAS-CHAVE: Pedro Kilkerry; verme; vocoperformance.
ABSTRACT: Pedro Militão Kilkerry (1885-1917) is an unknown symbolist poet, from Bahia, who has been avoided and under-researched by academics due to his reputation as a "difficult" figure. Our work focuses on both the poem and the song adaptation of "O verme e a Estrela", by Pedro Kilkerry, which was carried out by Cid Campos and recorded on the album $A$ Fábrica do Poema (1994), by Adriana Calcanhotto, on the verbivocovisual project Poesia é risco (1995), by Augusto de Campos. The aim of the present work is to analyse the remarkable poem "O verme a Estrela" and reflect upon the living and life-giving power of e-giving power of the voice and its vocoperformance which expands what is un derstood as merely graphic to new potent possibilities that ar hidden in page-state.

KEYWORDS: Pedro Kilkerry; worm; vocoperformance. 
Nascido em 1885 no município de Santo Antônio, na Bahia, e falecido em 1917, em Salvador, Pedro Militão Kilkerry foi poeta simbolista inserido na vertente que Antônio Carlos Secchin denomina "abstrato-construtivista, cujos principais cultores foram Mallarmé, em busca da 'poesia pura', e Rimbaud, cuja obra prenuncia a dicção surrealista” (2003, p. 140); em oposição à estética transcendente de Cruz e Souza (1861-1898) e Alphonsus de Guimaraens (1870-1921). Sem ter lançado um único livro em vida, acumulando apenas esparsas publicações de poemas e crônicas em jornais, Pedro Kilkerry só despertaria atenção, apesar de esforços anteriores do crítico Jackson de Figueiredo, após sua inclusão no terceiro volume do fundamental Panorama do Movimento Simbolist Brasileiro (1952), de Andrade Muricy; gesto solidificado e a mpliado pelo lançamento de ReVisão de Kilkerry (1970), a grande compilação-estudo do poeta, tradutor e crítico Augusto de Campos, responsável pela redescoberta revitalização de inúmeros nomes "afanados" pela tradição acadêmica, como Sousândrade (1833-1902), QorpoSanto (1829-1883)

Como legítima figura do limiar entre séculos, marcado no Brasil por um interregno entre as grandes eras do romantismo e do modernismo onde, na poesia, simbolismo e parnasianismo digladiaram esteticamente, coexistem em Pedro Kilkerry, este contemporâneo da Segunda Revolução Industrial, a marca irremovível de uma tradição ainda não inteiramente ressignificada (o que no Brasil só ocorreria na década de 1920, a qual ele, morto muito jovem ainda, não veria) e uma volição revolucionária que encontraria sua inspiração no simbolismo francês, principalmente na estética radical de Mallarmé, nas reflexões de Freud sobre o inconsciente, no crescimento urbano e no assomar de novidades tecnológicas como o cinematógrafo. Influências que, somadas a uma sintaxe incomum e uma irreverência lexical peculiar, iriam posicioná-lo como um precoce poeta moderno no Brasil.

O jovem bacharel em Direito, integrante de grupos de intelectuais baianos que orbitavam as revistas Nova Cruzada e Os Anais, Kilkerry seguiu um caminho bastante diverso de contemporâneos baianos como Xavier Marques e Artur de Sales, alguns de forte lastro parnasiano e outros de interlocução mais assinalada com o movimento simbolista. Kilkerry inclinou-se mais para o segundo. No entanto, fazendo das palavras de Cláudio Veiga (2004) as nossas, "foi bastante além". Quanto a isso, diz Augusto de Campos sobre o soneto "Cetáceo", linhas que poderiam ser aplicadas a diversos outros poemas de Kilkerry: 
[...] alto grau de conscientização da linguagem, uma intuição notável daquilo a que Décio Pignatari denominou de "isomorfismo" em poesia ("o conflito de fundo e forma em busca de identificação") e que outra coisa não é que a interação som-significado com que Jakobson caracteriza, essencialmente, a linguagem poética, identificando-a, por exemplo, em conjuntos fônicos como veni, vidi, vici, que nos fazem pensar nos dissílabos-chave de Kilkerry. (CAMPOS, 1985, p. 50)

Como Kilkerry era ta mbém um conhecedor do conceito de "inconsciente", o qual ele personificava em Rimbaud, em muitos sentidos o que o poeta intui é uma potência mágica da palavra poética, sem medo de desbravar a matéria aparentemente incompreensível da mente: o que torna sua abstração, paradoxalmente, mais consciente do que a de outros simbolistas. Ao se referir à inventividade lexical e imagética de Kilkerry, planeta literário em que lexemas inventados como "estangue" rimam com o pitoresco contundente e gráfico de "ondas de sangue", Augusto de Campos destaca o apreço de Kilkerry pelos neologismos: algo presente tanto em versos de poemas como "Harpa esquisita" quanto na série das kodaks, seu conjunto de prosas poéticas publicadas no Jornal Moderno, extinto periódico baiano. Dentro do inventário lexical kilkerrea no, contam-se verbetes como "mora mar", "monocular”, "cinemizar”, “esqueletar”, “desestrelar”, etc.
Em muitos casos, o neologismo não era recurso utilizado somente por gosto, mas também por necessidade. Lembremos que a própria solicitação de que o artista do fim do século XIX desse conta de todas as inovações que se sucedia $\mathrm{m}$ vertiginosa mente forçava-o à criatividade, a uma linguagem que se adaptasse a um mundo in progress.

Lembrando que este in progress não é sinônimo de progresso efetivo: a Belle Époque brasileira estava longe de ser uma real bela época. O Brasil já era uma nação assolada por desigualdades brutais (das quais o próprio Kilkerry era vítima, como veremos depois), contradições, instabilidade política e violência. Por isso e por tudo que sucedeu a implosão pós-procla mação no país, nossa Bela Época possui contornos decadentistas (o decadentismo brasileiro acabando por incorporar uma ideia mais ou menos afim: a de fracasso) visíveis tanto em Kilkerry quanto em Augusto dos Anjos (1884-1914), ainda que o pessimismo e o cientificismo brutal do segundo a tinjam um paroxismo que Kilkerry nunca almejou. Jackson de Figueiredo aventa, por sua vez, o que haveria no cerne disso:

[...] alguma coisa daqueles românticos ingleses do que disse Laurent que foram os mais românticos do mundo. A imaginação e a sensibilidade como predominantes, com tal força, na sua vida são a prova real do que digo, mas muito mais 
diretamente se ligava o seu espírito ao espírito francês numa das suas fases mais dolorosas e mais singulares -- aquela em que ainda soavam as notas mais ardentes e desordenadas da poesia de Verlaine e Rimbaud e, decadentes e simbolistas, se caracterizavam definitivamente em duas correntes quase opostas: uma, em que predominava o absoluto desprezo pelo academicismo da linguagem - a dos que seguiam Verlaine Laforgue, - e a outra que, com Mallarmé, René Ghil, Péladan, fazia distinção entre a linguagem artística e a linguagem prática, criando, por assim dizer, uma língua à parte para a comunicação de emoções estéticas. [...] Pedro Kilkerry, que adorava o Dante, pertencia, no entanto, àquele período da poesia francesa e lhe reproduzia aqui, integralmente, os ritmos mais desventurados que malditos. (FIGUEIREDO, 1985, p. 238-239)

Devemos criticar esse "afrancesa mento" da sensibilidade, um tanto redutor, mas não podemos ignorar a mentalidade e o contexto de Figueiredo e Kilkerry à época. Concentremo-nos em perceber o recorte que Kilkerry perfaz do simbolismo francês: ao mesmo tempo específico, numa localização temporal mais ou menos estanque, e a mplo, no que toca à quantidade e à qualidade das referências. Mais adiante, em uma série de citações-traduções de Histoire de la Littérature Française, de Lanson, Figueiredo arremata a análise poética de Kilkerry com este trecho do livro de Lanson que se adequa perfeitamente como síntese às crenças estéticas de Kilkerry, que comentaremos mais detidamente logo em seguida:

Para acordar a forma com a inspiração, a língua e o verso foram revolvidos. Tentou-se fazer mais individual a linguagem poética, libertá-la de todas as leis gerais que tendiam a uniformizar a expressão, a impor ao pensamento de um verbo de todos. O limite da expressão individual é o inteligível, e mais de um decadente ou simbolista, Mallarmé à frente, afrontou heroica ou ingenuamente esta barreira. Mas sem ir tão longe, muitos se esforçaram por esquivar-se às associações tirânicas, às convenções de regula ridade, de dignidade, de bom-tom: tentaram fazer um estilo que não exprimisse senão eles próprios e exprimisse tudo deles. Sobretudo acentuou-se uma tendência para transformar a natureza das relações gramaticais e sintáticas. As leis que presidem as relações das palavras tiveram sempre por fim o inteligível: as novas escolas quiseram que elas tivessem por fim o sensível. Agrupar as palavras não mais segundo a lógica, para realizar um sentido de todos perceptível, mas conforme a sensação, para manifestar uma impressão percebida pelo poeta, tão-somente, foi o fim mais ou menos conscientemente buscado. (FIGUEIREDO, 1985, p. 242-243)

Guardemos com zelo este trecho, principalmente por indicar a preponderância de um elemento musical ou 
sensorial sobre o sentido, o apreensível: é um sinal do gérmen musical, da sonoridade embrionária nas palavras de Pedro Kilkerry.

Sob perspectiva histórica, a modernidade ficcional e poética dos poetas brasileiros é consequência de uma realidade em transformação, para o bem e para o mal Homem de seu tempo, Kilkerry não era alheio a este fluxo ininterrupto de mutações. No sentido oposto de muitos contemporâneos seus, tentou enxergar a modernidade com clareza, e talvez por solitariamente fixar os olhos na escuridão da agoridade, tenha contraído sua própria obscuridade. Sua não-resistência diante do novo ("olhos novos para o novo! Tudo é outro ou tende para o outro", o baiano conclama, afirmação em que Campos enxerga um protótipo da sentença oswaldiana "ver com olhos livres") era um mote da época, pensando em escala global, mas é sua realização material, no artesanato textual, que configura efetiva mente a sua modernidade.

A professora Carmen Lúcia Negreiros de Figueiredo (2002) diz em seu artigo "Crítica à invenção do Brasil: paisagem, identidade, literatura" sobre Pedro Kilkerry, Augusto dos Anjos e outros autores que, ocupando as margens da tradição no limiar dos séculos XIX e XX, a dita Belle Époque brasileira, anteciparam criticamente muitas das questões modernistas:

No lugar das certezas elegem a dúvida, apresentando uma curiosidade profunda diante do novo, do futuro, do progresso para descobrir a fragilidade que os reveste; bordam o viés crítico num presente que suspeita da herança cultural e literária; indagam, na própria obra, com quais recursos a linguagem pode enfrentar a ideia de novo, sem se prender aos paradigmas do progresso inerentes às ilusões fomentadas no seu cotidiano (FIGUEIREDO, 2002, p. 27-28)

Kilkerry não é um assimilador irrefletido das novidades, não é o sujeito incapaz de experiência de Larrosa Bondía: sua postura é crítica, com matizes carregadas de sarcasmo. Por fim, é importante notar ta mbém que Kilkerry trata do próprio fazer poético, é o meta moderno antes de seu esvaziamento na pós-modernidade, algo que Campos chama de "autoperquirição mallarmaico-pessoa na” (CAMPOS, 1985, p. 43). Ressaltemos ta mbém o caráter substantivo de seus versos, na contra mão da "tara adjetival” de simbolistas. Diz o poeta-crítico concretista:

Kilkerry traz para o simbolismo brasileiro um sentido de pesquisa que lhe era, a té então, estranho, e uma concepção nova, moderníssima, da poesia como síntese, como condensação; 
poesia sem redundâncias, de audaciosas crispações metafóricas e, ao mesmo tempo, de uma extraordinária funcionalidade verbal, numa época em que o ornamento predominava e os adjetivos vinham de cambulhada, num borbotão sonoro-sentimental que ameaçava deteriorar os melhores poemas. (CAMPOS, 1985, p. 29)

Na poética de Kilkerry o cotidiano de fato se tornará matéria-prima para alguns de seus mais ousados experimentos formais, agora com a libertação do verso, em forma de crônica ou prosa poética. Em uma de suas crônicas-poemas mais famosas (legitimado o uso do adjetivo para qualificar a obra de poeta constantemente subestimado e ignorado) publicadas no Jornal Moderno, impressiona um dito como "o metro é livre: vivamo-lo", chamado direto à libertação formal uma década antes da abertura da Semana de Arte Moderna e materialização precoce de uma "conscientização dos novos meios" (CAMPOS, 1985, p. 61), disposição nada provinciana de dialogar criticamente com o novo mundo que se desvelava. Leia-se outro fragmento de crônica:

Nos bondes

Até meia-noite, o flirt nos bondes foi pacífico, numa fuzilaria macia...

Ligeiro sport em tempo de paz.
Este trecho pertence à série de publicações de estética recortada e fragmentária no Jornal Moderno, as kodaks, suas crônicas (se o nome servir) mais inventivas do ponto de vista formal. Se já destacamos o surpreendente esboço da filosofia estética modernista, agora o que chama a a tenção é o emprego pioneiro de um estilo de prosa poética que ganharia terreno em Oswald de Andrade e sua dita "prosa cinematográfica".

De fato, Kilkerry já aproximava sua linguagem da velocidade dos novos meios, como uma decupagem de imagens em uma sala de edição, jump cuts textuais, bem antes da telegrafia de Memórias Sentimentais de João Miramar (1924). Recomenda-se cautela com a palavra "inovação", todavia. É outro Campos, o Haroldo, quem comenta que Oswald (e, portanto, presumimos que Kilkerry antes deste) é melhor compreendido remontando às raízes muito bem fincadas da tradição. Assim, "veremos que o fragmentarismo da prosa oswaldiana (sobretudo do Miramar e do Serafim e culminando neles), assinalado por mais de um crítico, não é outra coisa senão a introdução e projeção em nosso romance da estética do fragmentário, que Hugo Friedrich vai identificar já na poesia e na prosa do último Mallarmé" (CAMPOS, 1985, p. 61-62). Kilkerry também era um antropófago, como o foram em alguma medida a maioria dos grandes artistas brasileiros. 
Muitos dos textos kilkerreanos, tais quais "Harpa esquisita" ou "Horas ígneas", poderia m render vultosos artigos, mas a nossa escolha foi guiada pela migração do poema da folha de papel para a voz. Também por sua modernidade e contenção formal sui generis, "O verme e a estrela" estaria fadado a um desconhecimento impiedoso não fossem a admiração e o afeto do crítico e filósofo Jackson de Figueiredo, grande amigo de Kilkerry, que guardou e publicou o poema.

"O verme e a estrela" foi publicado postumamente, a partir de um manuscrito, por Figueiredo em seu capítulo dedicado à obra de Pedro Kilkerry no livro de ensaios Humilhados e luminosos (1921), texto, aliás, presente como apêndice na ReVisão de Kilkerry de Augusto. Neste texto, o filósofo criticou o esquecimento de Kilkerry e fez uma apaixonada defesa de suas qualidades, como transcrevemos anteriormente.

\section{O VERME E A ESTRELA}

Agora sabes que sou verme

Agora, sei da tua luz.

Se não notei minha epiderme..

É, nunca estrela eu te supus

Mas, se cantar pudesse um verme,
Eu cantaria a tua luz!

E eras assim... Por que não deste

Um raio, brando, ao teu viver?

Não te lembrava. Azul-celeste

O céu, talvez, não pôde ser...

Mas, ora! enfim, por que não deste Somente um raio ao teu viver?

Olho, examino-me a epiderme,

Olho e não vejo a tua luz!

Va mos que sou, talvez, um verme...

Estrela nunca eu te supus!

Olho, exa mino-me a epiderme...

Ceguei! ceguei da tua luz?

Organizado em versos sáficos quebrados (octossílabos) distribuídos por três sextilhas, num arra njo difícil que repete a mesma organização e as mesmas rimas para a primeira e a terceira estrofes, o poema trabalha em chave simbólica o contraste entre o eu-lírico, o verme cego e telúrico, fisica mente incapaz de concretizar os gestos que deseja, e a estrela transcendente cuja luz, imagem convencional do simbolismo, cega por sua aguda luminescência ao mesmo tempo em que faz o eu-lírico ferido rebaixado a um helminto torpe, a sonhar com a visão que não mais detém. 
Faz-se sentir o aspecto sensorial marcado pelo poema na epiderme do próprio verme. Por sinal, "verme" e "epiderme" formam o par de rimas mais proeminente do poema, apontando uma potencial chave hermenêutica do poema: a terminação erme, enqua nto vocábulo independente, é ta mbém flexão de ermar, símile de solidão: o que indica sub-repticiamente o estado desse sujeito lírico perdido, diante da grandiosidade e da beleza inalcançáveis e incomensuráveis da estrela; além da fixação à luminosidade, à brancura e da intactibilidade do referente serem alguns dos aspectos que assinalam sua inscrição na tradição simbolista. Mais que isso: a reificação, desumanização do eu (notável também no caráter marcada mente substantivo, i.e. não-qualificativo dos versos) e o convívio do elevado com o grotesco e o prosaico, a partir de então posicionados em um contexto que os encaixam em outro nível discursivo, produzindo um Ostranenie (estranhamento), são procedimentos característicos da poesia moderna, que passou a relativizar a noção de sujeito lírico e as hierarquias entre lexemas no texto literário. Kilkerry joga com o eu-verme que é mais epiderme do que poema. Esta leitura ganha sentido levando-se em conta a cor da pele do poeta, num país tão racista como o Brasil.

Não confundamos a estrela com um valor positivo e o verme com uma negatividade antípoda. Kilkerry joga com estas aparentes oposições. Atentemos ao brevíssimo, mas perspicaz comentá rio de Augusto de Campos sobre o poema, em que ele afirma que o mesmo "parece insinuar um problema social ou racial", condensado "na alternância de imagens opostas ('verme e estrela', 'epiderme e luz') sutilmente reiteradas numa estrutura permutativa” (CAMPOS, 1984, p. 39). Kilkerry era um homem negro e pobre, vivo durante período de apogeu das teorias raciais no Brasil, que morreu na penúria e no esquecimento.

Esta luz, signo de brancura, que cega e queima o verme, não é um sublime positivo: remete, isto sim, à experiência do horror, vivenciada individual e coletivamente por todos os negados pela tradição social, cultural, estética. O protagonismo redentor do grotesco diante da brutalidade da beleza é uma exegese possível, que não anula a outra chave de leitura: o verme demonizado, a nimalizado, que se vê fustigado por uma clareza implacável que o subjuga, minora, desfaz de sua visão ou visiona rismo. Subjaz a estes versos também uma clave sarcástica, minimizada por Jackson de Figueiredo e enfatizada por Carlos Chiacchio (1985), como anotado por Ca mpos (1984, p. 45 ), por detrás do jogo chiaroescuro da poética kilkerreana e também deste poema. Como bem coloca Chiacchio, "o sarcasmo é um riso que dói” (1985, p. 271). 
Também é cabível relacionar este substrato social na epiderme do poema, locus do verme cantor, com aquele presente na obra do catarinense Cruz e Souza, poeta simbolista de renome. Por este viés sociológico, pode-se entrever um campo profícuo para estudos sob clave historiográfica da escola simbolista brasileira da vertente abstrato-construtivista, o simbolismo mais rimbaudiano, a qual, opinamos, ainda não foi suficientemente discutida e pensada no Brasil; e Kilkerry certamente não é o único exemplo em que nos a mparamos.

Produzindo de partida uma antítese conceitual bastante extrema, o poema a seu modo remete a outros momentos da literatura-mundo e do Brasil. Por exemplo, à agudeza barroca, quando principia a trabalhar ideias dia metralmente opostas, aproximando-as e afastando-as em virtude de um jogo de agudezas. Concebida como fantasmagoria ou presença espectral, a estrela que o verme nunca supusera apenas se beneficia da natureza mundana de seu cantor, dependendo justamente do brutal contraste para reluzir mais agudamente. Por esta seara não é o verme que se alimenta da estrela: é a estrela que suga a energia vital, que devora todas as potencialidades da criatura cantante. Ao verme, figurativização de um ser baixo que tem seus sentidos aniquilados pela presença tirânica do elevado, do inacessível, resta a súplica (suplício) do canto consolador, entendido este termo pela nomenclatura nietzschiana (2007) sobre a experiência trágica. A segunda estrofe, núcleo da transição do poema, já não é o espaço da súplica, do desfalecimento cego, mas do questionamento. Também é o único momento em que o sujeito enunciativo interrompe sua marcação, referindo-se somente ao sujeito do enunciado, a estrela, incapaz de dar um "raio ao teu viver". Há um quê de sarcasmo angustiado, aquele de que Kilkerry fora acusado por seus companheiros, nesse apelo inútil à estrela.

Outrossim, o poema sugere o lugar-comum do desejo angustiado pois impossível e, tema mais convencional ainda, o tropo da morte amorosa. Mas qual a natureza deste desejo? Justiça, Liberdade, Ascese, a própria Modernidade: não importa o que se busque, pois será inelutavelmente vedado ao verme. E o que seria a invalidez do verme senão a morte em vida, a interdição de sua capacidade de enxergar, a mar, sentir?

Formalmente construído com mão hábil e funcional, parcimonioso em adjetivações, lançando mão de rimas ricas, e.g. as terminadas em /us/ e /este/, e aditando especial ênfase à aliteração da fricativa dental desvozeada $[\mathrm{s}]$ (ou africada, a depender da dicção regional), que mimetiza duplamente o rastejar do anelídeo e a constituição 
fonológica da palavra "luz" (que ao ser invertida, vale notar, transforma-se no "zul" de azul-celeste), o texto dispõe estes elementos em proporção. A própria opção pelo octossílabo, organização métrica popular nos cancioneiros hispânicos e franceses (FALEIROS, 2007), sublinha uma opção peculiar que subentende uma musicalidade própria. Talvez fosse diálogo consciente com uma tradição cancional popular (de gosto afrancesado, novamente)? Não sabemos. Trata-se de questão menos relevante para o poema já musicado, embora um outro cancionista, que encontre para estes versos um modo de dizer diferente, possa se aproveitar desse paralelo.

Esta apropriação do grotesco e da palavra prosaica, a partir de então posicionada em uma circunstância que a eleva a outro nível discursivo, a uma potência impensada, impregnando as profundezas da alma e da mente humanas, é o tipo de procedimento que caracteriza a poesia moderna, a qual reconhece, em seu seio criativo, os ícones da decadência e do mundano. O gesto de atribuir ao verme decompositor uma voz lírica e cotejá-lo à estrela fulgurante tem força irmanada às dos anelídeos de Augusto dos Anjos, Edgar Allan Poe (1809-1949), Arthur Rimbaud (1854-1891), Machado de Assis (18391908), entre outros visionários que enxerga ra m seu valor moderno.
Refletindo sobre o verme que canta (que cantaria se pudesse), cumpre notar que o poema já apresenta pelo menos um aspecto a ser reforçado pela vocoperformance de Adriana Calcanhotto e Augusto de Campos (versão priorizada aqui): a materialização da voz até então imaginária do verme, literalizando seu canto. O verme não é mais eu-lírico, mas sujeito cancional de fato, a quem uma voz material foi concedida, elevando-o a uma nova condição. Deparando-se com esta necessidade de "formalizar" performaticamente o poema, Cid Campos presentifica e atualiza em voz o corpo escrito, limitado até o momento à epiderme textual. Defendemos que a performance dos cancionistas não somente reverencia Kilkerry, mas o atualiza. Isto é, preenche por intermédio da captura de sua entoação embrionária uma lacuna que passaria despercebida à crítica e à filosofia estético-poética de seu tempo, quando a discussão sobre as dissimilitudes entre poesia impressa e poesia oral e sobre a legitimidade da canção enquanto objeto verdadeira mente poético passava por um período de rarefação, desde o arcadismo exibindo uma prevalência canônica, mantida até hoje, do escrito sobre o falado.

Dificilmente concluiría mos que a adaptação cancional fosse, à época de produção do poema, confluência necessária das intenções conscientes de Kilkerry. Porém, 
incidentalmente ou não, há em sua intrincada construção uma vontade de voz, que talvez refletisse a própria modernidade instintiva de Kilkerry, espelhando o desejo do próprio sujeito lírico. O verme não quer falar ou escrever tampouco pede que o leiam: ele pede pela faculdade de cantar e pela faculdade de ser ouvido, pelo belo gesto que torne menos patética e incompatível sua relação com a estrela. Kilkerry implicitamente sugere que, enquanto nossos olhos, como os do verme, estiverem aturdidos pela luz ema nada do corpo celeste, ativemos os ouvidos e o tato, múltiplos sentidos que extrapolem o meramente "legível". Também destaquemos que a estrutura reiterativa do poema, com repetições de palavras e rimas que o aproximam da canção com refrão, facilita e justifica formalmente o trabalho do músico. Muito provavelmente a opção de Campos por "O verme e a estrela" e não "Harpa esquisita”, por exemplo, deve muito à sua própria organização poética.

Mesmo que a demanda da voz não venha expressa em um poema, o cancionista presume esse desejo quando busca a "entoação embrionária" (TATIT, 2006, p. 16-17) do poema, isto é, um princípio melódico-entoativo ocultado na palavra impressa, como uma voz que cantasse por detrás da abstração do poema lido e da leitura "decla matória" do poema, capaz somente de seguir o ritmo sugerido pela notação textual. Diferentes "entoações embrioná rias" podem ser encontradas para um mesmo poema, fazendo com que, apesar da manutenção da letra, diferentes versões tenham arranjos, tons, contornos entoa tivos e a té interpretações muito contrastantes.

Uma dúvida que paira sobre os pesquisadores de canção, sem nunca se encontrar uma resolução definitiva, é se a adaptação de um poema, sobretudo quando levada a cabo por outrem (i.e. um cancionista que não escreveu a letra), é uma a mpliação do objeto original, sua concretização ideal ou ainda um produto estético singular que, por sua natureza cancional, funda mentalmente difere do modelo emulado. Teóricos como Paul Zumthor (2010) e Ruth Finnegan (2008) prontamente descartariam a primeira opção, a de que a canção é ádito do poema impresso, pois defenderiam que a verdade formal do texto, sua mais importante potencialidade, estaria velada em sua virtualidade oral. Isto é, na voz que canta ou declama imaginariamente durante a leitura, que guia os sentidos corpóreos acionados pela participação estética, que "presentifica o ausente". Nas palavras de Portella em seu ensaio sobre Paul Zumthor, "o que define o ato perceptivo é o engajamento do corpo e da consciência que, simulta nea mente, recorrem à visão e aos outros sentidos, não somente como elementos com funções fisiológicas, 
mas como pensamento, olhar e espírito cujo desejo é ver e tocar as coisas sugeridas pela leitura" (PORTELLA, 2013 p. 233-234).

Um desejo de ver e tocar que é ta mbém o desejo do insólito verme kilkerrea no; verme que anuncia a seu modo a deriva anticanônica em que o nome de Kilkerry repousaria até seu resgate por Augusto de Campos. Ainda citando as palavras de Portella, a leitura poética segundo Zumthor é "a possibilidade de apreender, na palavra marcada no papel, o ausente-presente de um desempenho, de uma performance" (2013, p. 237).

Temos como ponto pacífico que a vocoperformance ostenta como características proeminentes a sua efemeridade (no sentido de que ocorre em um instante único do espaço-tempo, mesmo que reprodutível em um disco, arquivo de $\mathrm{MPB}$, etc.) e multiplicidade (pois a performance está sempre suscetível à variação, às modulações da memória, ligada ta mbém às que a precedem e sucedem), que a singularizam enqua nto ato performativo sempre sob condições de recepção distintas. Por várias razões, acreditamos que isto tenha sido apenas aparentemente relativizado pelo advento da indústria fonográfica. De fato, uma vocoperformance, mesmo gravada, nunca mais será a mesma, ainda que siga estritamente o roteiro de sua letra e melodia, pois o leitor-ouvinte e as condições de leitura/escuta ta mbém nunca são os mesmos. A vocoperformance no momento de sua realização é, paradoxalmente, completa em si mesma, mas ta mbém dependente das outras (da memória das outras), adquirindo um caráter movente.

Neste ponto, até mesmo a leitura do texto impresso, em sua qualidade de "performance de recepção", está ta mbém suscetível a modulações semânticas proporcionadas pelo conta to individual e único com a obra de arte. No caso, emissor e receptor são co-arquitetos do texto (impresso ou oral; ou não-oralizado e oralizado), mas a construção pregressa sempre desaba para dar lugar a uma outra, ressemantizada, qua ndo estes arquitetos do sentido se reencontram. Toda performance, mesmo a contida em um CD, é única; como toda releitura de um mesmo livro também é única. $\mathrm{E}$ a estabilização das performances de execução (i.e., a gravação fonográfica) não parece ter solapado este entendimento. Para Lucas de Mello Cabral e Matos:

O autor nos diz que o poema é suas performances, vale dizer suas vá rias versões em suportes e com ma terialidades diferentes. Como ele mesmo reconhece, admitir tal ideia implica não reconhecer preponderância de nenhuma versão original ou 
final sobre as outras, e trabalhar com, ou mesmo a partir de, as incompatibilidades, o que é descontínuo entre uma performance e outra. Do ponto de vista do autor, as performances gravadas (em áudio ou com suportes a udiovisuais), ou ao vivo, bem como as performances impressas compõem problematicamente o evento plural do poema, que não apresentaria uma identidade ou essência fixa. (MATOS, 2016, p. 49)

Quando aplicada a casos específicos, concordamos com essa ideia de "poema plural", em conformidade com o projeto verbivocovisual, que apla na as dimensões visual, fonética e linguística do poema. Entretanto, cada caso é um caso: alguns são mais colaborativos e livres, outros são supervisionados por um único artista ou grupo de artistas. É possível desca racterizar completa mente um poema em sua versão cancional, enfraquecendo-o ao invés de fortalecê-lo.

Se a luz aniquila o verme, e se a canção complica a hegemonia de um autor, quem falaria não seria mais o verme, mas sim a sua projeção fantasmática - a voz de Cid Campos, Augusto de Campos ou Adriana Calcanhotto? O sujeito do limiar que dividiu século XIX e século XX é atualizado quase um século depois, em outro limiar (século XX-XXI), transmutando-se por si só em uma fantasmagoria do passado. $\mathrm{O}$ verme não é somente a criatura malfeita e suja, mas o falante anacrônico, antigo, voz de uma república incipiente e de um país recém-saído da escravidão; mais que isso, a voz de uma entidade de fato fantasmática, pois morta, congelada no tempo, precisando do outro para se fazer presença.

Ou seja, assim como o trabalho de compilação e crítica de Augusto de Campos sobre a obra poética de Pedro Kilkerry de algum modo revitalizou este poeta, a bem da verdade ainda bastante obscuro, é o filho do poeta-crítico, Cid Campos, quem intensifica esta vitalidade com a concessão de uma voz física que insira Kilkerry no território vasto da poesia cantada e popular contemporânea. Não se trata talvez de ressuscitar, mas dar à luz finalmente o que sempre existiu apenas como sugestão de vida, presença incompleta, existência subalternizada, a partir do instante em que o cancionista capta a existência de uma entoação embrionária, a potência musical, à espera de ser cumprida. A voz de alguém cantando indica que há um indivíduo de carne e osso existindo. É esta unicidade o que assusta. Ter voz é ser um existente. Para Adria na Cava rero, "parece que antes do advento da metafísica era mais natural acreditar que o pensamento fosse um produto dos pulmões. [...] O raciocínio é elementar: o pensa mento se liga à palavra, e a palavra à voz e à respiração" (CAVARERO, 2011, p. 84). “Se cantar pudesse 
um verme, / Eu cantaria a tua luz", diz o pré-metafísico verme de Kilkerry, essa voz que fala por trás da voz que canta em Calcanhotto e Campos.

Em certo sentido, a música invoca o tipo de recepção ideal da experiência estético-ritual: o do ouvinte estético, estipulado por Nietzsche (2007) em contraposição ao "crítico". O crítico seria a corrupção distanciada e afrouxada pelo socratismo científico. Por sua vez, o antigo apreciador (e participante) dos ditira mbos e, após, da alta tragédia ática, o homem arrebatado pelo turbilhão dionisíaco (mas salvo pelo princípio de individuação apolíneo, que lhe permite ainda ser ele mesmo em meio ao caos extático), é o ouvinte estético que está aberto para um "além do entendimento". Este receptor ideal possui um dom de intuição que se perdeu, esmagado pela racionalidade: "Agora sabes que sou verme", diz a voz do poema de Kilkerry. Não se trata de um superficial e limitado homem douto: está mais para um louco, no sentido menos pejorativo e mais criativo da palavra, que enxerga/ escuta além da superfície, da epiderme.

Ora, se a canção pode ser um chamamento mais direto aos sentidos, isto não deve ser interpretado como se sua fruição fosse atitude de desligamento intelectual ou preguiça hermenêutica. A confusão de associar a sensualidade do corpo à ignorância é o tipo de preconceito que é preciso superar. Antes disso, o artesa nato cancional opera seus signos de modo mais amplo, irrestrito, com ecos mais imediatamente físicos, colocando em xeque o valor predominante do conteúdo do enunciado gramatical e sua reprodução textual como suprassumo da comunicação humana. Em verdade, ao nos referirmos a estes conceitos basilares (i.e. gramática e textualidade) dos estudos linguísticos, semióticos, etc., devería mos ter em mente sua incompletude fundamental.

Uma vez constatado que as ideias de cânone literário para Augusto de Campos, no seio do projeto verbivocovisual, frequentemente são dispostas sem uma tentativa de "sequestro" do poético, original e fundamentalmente oral, por uma hegemonia do escrito, eis a força do gesto de cantar o verme, o ser que subalternizado agora canta pela garganta de alguém. É admissível que o escrito, em sua qualidade formal, seja uma entidade inviolável e absoluta do ponto de vista de seu suporte físico. Por isso, ao adaptar os poetas de seu paideuma pessoal a um projeto de modernização da palavra poética, Augusto de Campos injeta vida naquilo que a tradição relegou a estatuto de museu tipográfico, i.e., a palavra escrita, sem que se pense a sério as dimensões vocal, visual (a nível tipográfico) e performática. 
A vocalização do poema, encontrada sua "entoação embrioná ria”, concretizaria a descoberta/a tribuição de seu valor musical e, nos eventos específicos de sua incorporação por cancionistas contemporâneos como Cid Campos e Adriana Calcanhotto, associariam esse valor a uma modernidade que já existiria (CAMPOS, 1983, p. 13) na matéria textual impressa de Kilkerry, mas que é agora iluminada pela voz física.

Conferir voz ao verme traz consigo o necessá rio investimento de uma "tensividade" à canção. Tanto na versão de Calcanhotto quanto na de Cid, na fala deste verme híbrido que canta ora com voz feminina-estrela, ora com voz masculina-verme, constata-se um prolongamento de vogais típico do procedimento de passionalização (TATIT, 1996, p. 22), que modaliza o ser do sujeito cancional, inserindo-se na performance como cerne de uma entonação melódica que pode soar apaixonada e/ou lamuriosa. O verme está extasiado e ferido simultaneamente; e talvez um destes predicativos seja decorrente do outro. Simultaneamente, incorporar à sua a voz da estrela, faz a identidade do eu deslizar entre os polos predefinidos de ser e estar no mundo.

A dominância da passionalização desvia a tensão para o nível psíquico. A ampliação da frequência e da duração valoriza a sonoridade das vogais, tornando a melodia mais lenta e contínua. A tensão de emissão mais aguda e prolongada das notas convida o ouvinte para uma inação. Sugere, antes, uma vivência introspectiva de seu estado. Daqui nasce a paixão que, em geral, já vem relatada na narrativa do texto. Por isso, a passionalização melódica é um ca mpo sonoro propício às tensões ocasionadas pela desunião amorosa ou pelo sentimento de falta de um objeto de desejo. (TATIT, 1996, p. 23)

Entretanto, a canção no disco de Calcanhotto também força o ouvinte a lidar com um momento de ruptura desconcertante, de "estranhamento": a voz de Augusto de Campos, que surge decla mando a segunda estrofe do poema, em tom incongruentemente solene, contrastando com os artifícios técnico-melódicos utilizados por Adria na Calcanhotto e Cid Campos em suas performances passionalizadas. Como um contraste entre o verme rasteiro, sujo, sombrio, e a estrela brilhante, radiante, iluminada. Ao convocar a estrela Augusto para declamar os versos, a voz sublime e estrangeira do poema - "E eras assim... Por que não deste / Um raio, brando, ao teu viver? / Não te lembrava. Azul-celeste / O céu, talvez, não pôde ser... / Mas, ora! enfim, por que não deste / Somente um raio ao teu viver?" - Calca nhotto presta homenagem a Augusto e a Kilkerry, pelo modo como o autor de "Pós-tudo" decla ma a fala do ser-cantado, não 
do ser-cantante; além de entrar no jogo das regras que definem as identidades do verme a da estrela.

Há um pormenor que diferencia a versão de Calca nhotto e a versão de Cid Campos: somente na versão de Calcanhotto, durante a parte final da canção, a estrofe decla mada por Augusto de Campos se sobrepõe ao canto de Calcanhotto. Esta sobreposição inesperada de vozes ilumina alguns pontos: primeiro, há a possibilidade de que não seja apenas um único sujeito lírico entoando a canção. $\mathrm{O}$ eu é verme porque não pode cantar, mas, ao mesmo tempo, é estrela porque recla ma da impossibilidade de canto. Arma-se aqui um complexo jogo metapoético, sublinha ndo na justaposição de vozes na canção de Calcanhotto. A solenidade consciente - à la século XIX - de Campos pode significar a voz da tradição, a voz do próprio Kilkerry, ou mesmo da estrela, que hipocrita mente cobraria o impossível do verme, fortalecendo ainda mais o subtexto autoirônico que os leitores mais a tentos de Kilkerry não sonega ram. Ou ainda, é um signo do hibridismo do verme, a ferindo uma universalidade à sua experiência.

A voz que canta prenuncia, para além de um certo corpo vivo, um corpo imortal. Um corpo imortalizado em sua extensão timbrística. Um corpo materializado nas durações melódicas.
[...] A voz que fala, esta sim prenuncia o corpo vivo, o corpo que respira, o corpo presente, na hora do canto. [...] Dessa singular convivência entre o corpo vivo e o corpo imortal brotam o efeito de encanto e o sentido de eficácia da canção popular. (TATIT, 1996, p. 16)

Se o canto já presume a convivência das duas vozes, a voz que declama é como um eco oriundo do século XIX uma projeção fantasmática de outro tempo: um poeta simbolista que adentra, "possui" a voz e o corpo vivos de Augusto de Campos, para posicionar-se no presente, criatura diacrônica, dessemelhante, finalmente peça ativa no jogo da modernidade que previra naquela fronteira finissecular. É ta mbém a voz preocupada com a "inteligibilidade”, a precisão da pronúncia; voz leitora que assoma reverente e deslocada. A voz que canta, por sua vez, uma expressão de sua própria modernidade (aparente nos temas e nas imagens), que se desnuda no desentra nhamento de sua prosódia, de sua entoação embrionária; que por meio de Cid Campos e Calcanhotto ganha vestes menos vetustas e pomposas, atualizando-se e erotizando-se, jogando um jogo sincrônico impreterível à performance. Esta voz não se subordina aos seus cancionistas, ainda que a performance esteja delimitada pelos contornos da dicção e do arranjo. A voz cantora chama os vários outros que compõem a individualidade do eu-lírico para si, 
o leitor/ouvinte; os performers; o próprio Pedro Kilkerry, compondo um poliedro coletivizado de vozes, paradoxalmente humanizando-o, através da fala, e imortalizando-o, através do canto, na mesma medida.

Outro ponto relevante é que Augusto de Campos, com sua própria voz, é quem não permite que a canção se coloque acima ou abaixo do poema: o intuito é desierarquizante, tratando com igual reverência as potencialidades próprias da melodia musical e a natureza gráfico-visual portanto legível, do poema impresso. O disco Poesia é risco vem acompanhado de um encarte-livro com os poemas impressos, respeitando-os em sua forma e disposição gráfica originais. Trata-se afinal de um projeto verbivocovisual, no qual as distintas instâncias da palavra (verbal, vocal e visual) coexistem e apla nam-se valorativamente. Dito isso, para Cláudia Neiva de Mattos, "no fundo, são as palavras que mais contam. Imbricado no exercício estético-sensorial, o eixo de tudo permanece sendo o código verbal, o texto cuidadosa mente enunciado por uma voz que se mostra, pode-se dizer, respeitosa, quase reverente, diante da palavra que pronuncia" (MATOS, 2010, p. 103).

Ao nos voltarmos para um conteúdo cancional, nossa primeira postura consciente talvez não seja atentar a "como" é dito o que é cantado, nem para as relações que se estabelecem entre a gramaticalidade da letra (i.e. o significado imanente à parte puramente lógico-proposicional, ao conteúdo semântico da palavra) e o manejo musical destes enunciados pela entoação, pela acentuação, pela melodia, por todo o aparato sonoro, na voz e fora dela, que estende sua teia de significação para além do óbvio semântico. Isto porque uma canção pode ser mero balbuciar, grito, murmúrio inaudível, mantra, e ainda assim possuir uma espécie de significação. A canção investe na fonética, a dimensão mais primária e esvaziada da linguística.

O linguista e teórico da canção Luiz Tatit anota que "quando a palavra falada quer atingir longe, no grito, no apelo e na declamação, ela se aproxima caracteristicamente do canto e vai deixando aos poucos de ser instrumento oral para se tornar instrumento musical, [...] perder a função fonológica e a pertinência linguística. Significa trocá-las pela função fonética e pela pertinência musical” (TATIT, 1996, p. 14). Não que a canção deva necessariamente perder por completo sua função fonológica. Entretanto, para um teórico da poesia, a linguagem poética pode reinstalar a plenitude semântica das palavras desgastadas pelo uso corriqueiro, banal; na canção, a plenitude semântica, mesmo que com o uso 
da voz, mesmo que com o uso do órgão língua, pode ser alcançada sem a necessidade de palavras.

Ainda que não esteja mos pensando conceitualmente sobre as operações que são imediatamente ativadas (ou reativadas) em nosso corpo, somos cativados pela voz de alguém cantando. Nem sempre o primeiro gesto que nos sobrevém é o de "explicar" racionalmente o porquê de uma dada canção nos comover profundamente. Contudo, com um pouquinho de inteligência, podemos intuir que o que incide sobre nosso corpo é mais que um arrebata mento inexplicável de nossa sensibilidade: é efeito pretendido. Porque o cancionista, trovador cujo artesana to é feito dessa materialidade impalpável (e, portanto, paradoxal) da voz, que, todavia, parece mais real do que a abstração mental de que a palavra gráfica é mera transcrição, o cancionista realiza escolhas, opções estéticas, experimentações, que pressupõem um cuidado detido ao que a voz revela e oculta. Em outras palavras, existem operações e técnicas específicas da composição de canção que são exclusivas desta modalidade de poesia.

Mesmo sendo um arauto da modernidade (e do modernismo) no Brasil, com uma obra que resistiu com honras à prova do tempo, Pedro Kilkerry continua obscuro, pesquisado insuficientemente. Malgrado sua obscuridade, nosso artigo não guarda somente o intento de atestar a vitalidade de Kilkerry. Trabalhos acadêmicos de qualidade nos precedem e especialistas sérios como Rodrigo Ugá (2011) e Jiego Ribeiro (2015). Que um poema como "O verme e a estrela", mesmo migra ndo de período, do início para o fim do século XX, e de suporte, do papel para a voz, mantenha sua atualidade e sua força, é apenas prova de seu gênio incomum, que merece mais.

Assim, com um duplo objetivo, nosso artigo elaborou e investigou a obra deste sarcástico e trágico simbolista baiano ao mesmo tempo em que confirmou as modulações de sentido provocadas pela adaptação cancional, sublinhando suas especificidades e criando espaço para novos campos de discussão na área de estudos de poesia cantada. Entendemos que adaptar cancionalmente Kilkerry não é mera homenagem: é revelação. Não apenas de suas qualidades rítmicas e métricas, não apenas de sua força prosódica, mas também de uma demanda da voz que acresce novas camadas de significação. É também uma integração caleidoscópica de subjetividades: Kilkerry, Augusto de Campos, Cid Campos, Adriana Calcanhotto, o leitor/ouvinte em sua própria performance de recepção.

REFERÊNCIAS 
CAMPOS, Augusto de. ReVisão de Kilkerry. $2^{\mathrm{a}}$ ed. São Paulo: Editora Brasiliense, 1985

Poesia é risco (CD). Rio de Janeiro: Polygram, 1995.

CALCANHOTTO, Adriana. A fábrica do poema (CD). São Paulo: Sony, 1994

CAVARERO, Adriana. Vozes plurais: filosofia da expressão

vocal. Trad. Flávio Terrigno Barbeitas. Belo Horizonte:

Editora UFMG, 2011

CHIACCHIO, Carlos. "Pedro Kilkerry". In: ReVisão de

Kilkerry. $2^{a}$ ed. São Paulo: Editora Brasiliense, 1985.

FALEIROS, Álvaro. "Elementos para a tradução do

octossílabo em português". In: Cadernos de Literatura em

Tradução. São Paulo, SP: Universidade de São Paulo, n. 7 .

2007

FIGUEIREDO, Jackson de. "Pedro Kilkerry". In: ReVisão de

Kilkerry. $2^{a}$ ed. São Paulo: Editora Brasiliense, 1985.
FIGUEIREDO, Carmem Lúcia Negreiros de. "Crítica à invenção do Brasil: paisagem, identidade, literatura". In:

Terra roxa e outras terras - Revista de Estudos Literários.

Vol. 2. Londrina: Universidade Estadual de Londrina, 2002.

FINNEGAN, Ruth. "O que vem primeiro: o texto, a música ou a performance?" In: MATOS, Cláudia N.; TRAVASSOS,

Elizabeth; MEDEIROS, Fernanda T. (Orgs.). Palavra cantada: ensaios sobre poesia, música e voz. Rio de Janeiro: 7 letras, 2008, p. 15-43.

MATOS, Claudia Neiva de. "Vanguardas poéticas e tecnologias sonoras: poesia é risco". In: Revista Matraga Rio de Janeiro: Pós-graduação Letras UERJ, v.17, n.27, jul./ dez. 2010

MATOS, Lucas de Mello Cabral e. "Ouvido também lê: algumas palavras sobre performances vocais do poema". In PEDROSA, Célia; e ALVES, IDA (orgs.). Sobre poesia: outras vozes. Rio de Janeiro: 7Letras, 2016.

NIETZSCHE, Friedrich. $\mathbf{O}$ nascimento da tragédia ou

helenismo e pessimismo. Trad. Jacó Guinsburg. São Paulo, SP: Companhia das Letras, 2007. 
PERRONE-MOIMES, Leyla. "Espectros da modernidade literária". In: Mutações da literatura no século XXI. São Paulo: Companhia das Letras, 2016.

PORTELLA, Mirtes Maria de Oliveira. "A leitura silenciosa do texto literário: uma experiência perceptiva e performática". In: Agamben, Glissant, Zumthor: Voz. Pensamento. Linguagem. São Paulo: EDUC, 2013.

RIBEIRO, Jiego. Máquinas fantasmas na escritura: a modernidade em Pedro Kilkerry. Espírito Santo: EDUFES 2015

SECCHIN, Antonio Carlos. Simbolismo e modernismo. In Escritos sobre poesia \& alguma ficção. Rio de Janeiro: EdUERJ, 2003

STAIGER, Emil. Conceitos fundamentais da poética. Rio de Janeiro: Tempo Brasileiro, 1997.

SÜSSEKIND, Flora. Coro a um - Notas sobre a

“cançãonoturnadabaleia". In:Gragoatá, n.12, p. 23-46.

Niterói: EdUFF, 2002

TATIT, Luiz. "Dicção do cancionista". In: O cancionista:

composição de canções no Brasil. São Paulo: EDUSP, 1996
A arte de compor canções. In: Revista USP, n 111, 2016.

A ilusão enunciativa na canção. In: Per Musi

Belo Horizonte, n. 29, 2014, p. 33-38.

ZUMTHOR, Paul. Performance, recepção e leitura. Trad. Jerusa Pires Ferreira e Suely Fenerich. São Paulo: Cosac Naify, 2007.

Introdução à poesia oral. Trad. Jerusa Pires Ferreira, Maria Lúcia Diniz Pochat, Maria Inês de Almeida. Belo Horizonte: Editora UFMG, 2010.

EM TESE

BELO HORIZONTE

v. 26

N. 3

SET.-DEZ. 2020

SANTOS; OLIVEIRA. A voz do verme híbrido e transtemporal de Pedro Kilkerry P. 38-57 